художніми навичками. Зміна парадигми мистецької освіти передбачає оновлення цілісного культурологічного комплексу освітянських орієнтирів, формування художньо-інформаційної культури особистості. Це, в свою чергу, викликає необхідність розроблення нових освітніх технологій, що грунтуються на поєднанні як традиційних, так i сучасних (мультимедійних, мережевих, електронних) способів підтримки творчого самовираження особистості у мистецьконавчальному просторі.

\title{
Література:
}

1. Зайцева А. В. Художньо-комунікативна культура майбутнього вчителя музичного мистецтва: теорія, методологія, методичні аспекти: монографія. - К.: НПУ імені М.П.Драгоманова, 2017. - 255 с.

2. Падалка Г.М. Педагогіка мистецтва (Теорія і методика викладання мистецьких дисциплін). - К.: Освіта Україна, 2008. 274 с.

DOI https://doi.org/10.30525/978-9934-588-80-8-2.61

\section{ЯКІСНА МЕДСЕСТРИНСЬКА ОСВІТА - ВИМОГА СУЧАСНОГО УКРАЇНСЬКОГО СУСПІЛЬСТВА}

Iсаєва O. C.

кандидат філологічних наук, доктор педагогічний наук, професор кафедри педагогіки та інновачійної освіти Національний університет «Львівська політехніка», дочент кафедри латинської та іноземних мов Львівський національний медичний університет імені Данила Галицького

Хміляр I. P.

аспірант кафедри педагогіки та інновачійної освіти Національний університет «Львівська політехніка», викладач вищої кваліфікаційної категорії,

викладач-методист кафедри соціально-гуманітарних дисииплін ВНКЗ ЛОР «Львівська медична академія імені Андрея Крупинського м. Львів, Україна

Сучасні умови модернізації медичної галузі й медсестринства зокрема передбачають потребу в реформі медичної освіти та запровадження інноваційних методів щодо навчання та розвитку потенціалу працівників первинної ланки. У липні 2018 року впроваджено 
проєкт «Стратегії розвитку медичної освіти в Україні до 2028 року», де особлива увага приділяється представникам первинної ланки медикосанітарної допомоги. Реформування системи медичної освіти, оволодіння основними компетенціями, формування вмінь та навичок студентів медсестринської справи, підвищення результативності й ефективності послуг охорони здоров'я розглядається як важлива складова стратегії розвитку та становлення оновлених стандартів. Адже методика підготовки молодших медичних фахівців повинна корелювати 3 європейськими стандартами і запитами сучасного суспільства 3 огляду на виклики епідемій чи навіть пандемій. У сучасних умовах працівники первинної ланки перші мають контакт 3 паціснтами 3 підозрою на COVID-19 і повинні прийняти правильне рішення щодо госпіталізації пацієнта чи його лікування вдома.

У грудні 2018 року розпочався україно-швейцарський Проєкт «Розвиток медичної освіти в Україні», який триватиме до кінця 2022 року і надаватиме матеріально-технічну підтримку для пілотних закладів вищої освіти для медсестер:

1) вищий навчальний комунальний заклад Львівської обласної ради «Львівська медична академія імені Андрея Крупинського»;

2) комунальний вищий навчальний заклад «Житомирський медичний інститут» Житомирської обласної ради;

3) комунальний заклад вищої освіти «Рівненська медична академія» Рівненської обласної ради.

Проєкт «Розвиток медичної освіти в Україні» заснований Швейцарським інститутом тропічної медицини та громадського здоров'я (SwissTPH) за підтримки Швейцарської агенції з розвитку та співробітництва (Swiss Agency for Development and Cooperation - SDC) i передбачає запровадження нової ролі медичної сестри, тобто розширення ії знань і компетенцій, а також розвиток клінічних навичок середнього медичного персоналу. Отож, медсестри потребують якісного тривалого навчання в закладах освіти. В обраних пілотних закладах Проєкт фокусуватиметься на таких завданнях:

- відкриття та оснащення симуляційних центрів у пілотних закладах для опанування базових клінічних навичок;

- зростання привабливості закладу освіти для студентів відповідно до впровадження інноваційних технологій, а саме системи е-навчання;

- зростання престижу закладу освіти для викладачів завдяки збільшенню можливостей професійного розвитку через організацію тренінгів щодо студентоцентричного навчання та створення можливостей для міжнародної співпраці;

- посилення академічної доброчесності в навчальному закладі; 
- розвиток найкращих практик в освітньому процесі та клінічній практиці завдяки міжнародній співпраці;

- розбудова дослідницьких можливостей у закладі освіти;

- підвищення інституційної спроможності щодо ведення проєктної діяльності [3].

Особливої уваги заслуговує твердження науковця Р. Неділько, що за фактором ефективності та якості медсестринську освіту в Америці вважають однією із найкращих. Оскільки основа медсестринської освіти США базується на ступеневості як етапах до складання ліцензійного іспиту студентами. Важливим також $є$ той факт, що випускники медсестринських ВНЗ у США мають великі перспективи в розвитку подальшої своєї кар'єри. Окрім того, вони можуть самостійно проводити приватну практику та приймати пацієнтів [2, с. 117], що необхідно поетапно запроваджувати і в нашій державі. Саме тому реформування медичної галузі $\epsilon$ першочерговим та потребує практичних реформ і якісної освіти.

Отож, анонсування Проєкту в навчальних закладах передбачає: покращення освітнього середовища; підвищення ефективності навчання згідно із сучасними комп'ютеризованими системами управління (онлайн навчання) та інвестиціям в медичну літературу; форсування студентоцентричного підходу в медичній освіті та удосконалення педагогічних компетенцій викладачів; оновлення освітніх програм 3 акцентом на: а) гармонізацію зі стандартами об'єктивного структурованого клінічного іспиту; б) навчанні, орієнтованому на вміння (клінічні навички); інвестування в інфраструктуру викладання клінічних навичок та забезпечення необхідного розвитку організаційної структури для забезпечення загальної результативності та сталості; підтримка кафедр загальної практики та сімейної медицини в університетах шляхом стимулювання дослідницьких компетенцій, знання англійської мови та підтримка інших заходів тощо [3].

Варто зазначити, що «6 квітня 2020 року Міністерство охорони здоров'я та громадські організації представили демоверсію перших складових «е-Health» - програми, яка об'єднає реєстри медичних закладів, лікарів та пацієнтів» [1], що вважається надзвичайно важливим для фахівців первинної ланки. Адже саме медсестри повинні бути добре обізнаними щодо ведення чи реєстрації пацієнтів у цій програмі. У цьому контексті постає проблема поєднання традиційних методів навчання 3 новими інформаційно-комунікаційними технологіями такими як: peer-groups, тобто «горизонтальне» навчання медсестер, де відсутній тренер, натомість $є$ формат «спілкування» обговорення щоденних клінічних випадків, обміну практичним досвідом, організаційними моментами й учасники комунікують щодо 
процесу надання фахової медичної допомоги; e-learning, метою якого $\epsilon$ використання сучасних технологій у навчанні, а саме освітні платформи, де можна безкоштовно заходити й завантажити презентації лекцій, завдань, тестів тощо. Такий підхід уможливлює проходження тестів, читання сучасної наукової літератури, отже, значно спрощує підготовку студентів до занять, тобто передбачає індивідуальний стиль професійної діяльності майбутніх фахівців.

Уважаємо, що з метою сприяння систематичного розвитку медичних фахівців первинної ланки необхідно:

- проводити роботу щодо забезпечення підвищення кваліфікації і професійних навичок персоналу медсестер;

- розробити і впроваджувати нові технології у сфері сестринської допомоги;

- надавати консультативну сестринську допомогу;

- забезпечити високий рівень медичної інформації;

- проводити санітарно-просвітницькі та профілактичні бесіди 3 населенням;

- проводити науково-дослідну роботу в галузі медсестринства;

- започаткувати навчальні школи, тренінги чи вебінари 3 метою удосконалення базових компетенцій, які забезпечують збереження i відновлення здоров'я;

- окреслити оновлені стандарти обов'язків медсестри.

Отже, реформа медсестринської галузі в пілотних вишах допоможе поширити досвід застосування успішних підходів на національну та міжнародну рівнях і в подальшому забезпечить якісну медичну допомогу населенню.

\section{Література:}

1. Ісаєва О.С. Інноваційні технології в медичній освіті / О.С. Ісаєва // Науковий журнал «Інноваційна педагогіка». - Одеса: ПУ «Причорноморський науково-дослідний інститут економіки та інновацій», 2020. Випуск 23. - Том 1. - С. 124-128. https://doi.org/ 10.32843/2663-6085

2. Неділько Р. В. Зарубіжний досвід державного регулювання розвитку освіти в медсестринстві / Р. В. Неділько // Інвестиції: практика та досвід. -ТОВ «ДКС Центр», 2016. - № 17. - С. 116-118.

3. Професійний розвиток освітян, лікарів та медсестер в нових умовах: час для діалогу? Журнал «Медична справа». https://www.medsprava.com.ua/news/2465-profesyniy-rozvitok-osvtyanlkarv-ta-medsester-v-novih-umovah-chas-dlya-dalogu? 